Journal of Primary Education
$9(3)(2020): 267-277$
UNNES
https://journal.unnes.ac.id/sju/index.php/jpe

\title{
The Effectiveness of Symbolic Modeling Learning to the Early Children's Expressive Language Skills
}

\author{
Dwi Asmiarti $^{1 凶}$, Kurotul Aeni ${ }^{2}$, Mulawarman Mulawarman $^{2}$ \\ DOI: https://doi.org/10.15294/jpe.v9i3.39747 \\ 1.TK PGRI Tanggel, Pati, Jawa Tengah, Indonesia \\ 2. Pascasarjana, Universitas Negeri Semarang, Indonesia
}

\begin{tabular}{l} 
Article Info \\
\hline History Articles \\
Received: \\
20 February 2020 \\
Accepted: \\
15 March 2020 \\
Published: \\
31 May 2020 \\
\hline Keywords: \\
Expressive langauge, \\
symbolic modeling
\end{tabular}

\begin{abstract}
Early children need language to express their ideas. Thus, they will need to master expressive language skills. This research aims to find out the effectiveness of the symbolic modeling learning model assisted by using a doll toward the early children's expressive language skills. This is experimental research with a pretest-posttest control group design. The population of the research consisted of 30 children aged 5-6 years old in PGRI Sarimulyo and PGRI Sarimulyo 02 preschools. The data were taken by purposive sampling on 30 children aged 5-6 years old. The data collection technique was observation sheets of expressive language skills with a 1-4 liker scale. Wilcoxon test and the Mann Whitney test were applied to test the hypothesis. The result show that the symbolic modeling method assisted by a doll is effective for the students learning outcomes after being intervened. It proves that the symbolic modeling method assisted by a doll is effective to improve the expressive language skills of early childhood children at PGRI Sarimulyo Kindergarten
\end{abstract}

\footnotetext{
Correspondence address:

Tk PGRI Tanggel, Kecamatan Winong, Kabupaten Pati

Klegen, Tanggel, Winong, Kabupaten Pati, Jawa Tengah 59181

p-ISSN 2252-6404

e-ISSN 2502-4515

E-mail: dwi.asmiart@gmail.com
} 


\section{INTRODUCTION}

Language consists of both written, spoken, or sign communication-based on a symbolic system. It is very important for children because they need language to describe their pasts and to plan their futures (Santrock, 2008: 67).

Language skill is usually grouped into expressive and receptive skills. Fauzani (2016), in his research, concluded that expressive language skill consists of speaking and writing. It involves a meaning transfer through symbols that are processed and expressed by children.

Language skill is important and must be owned by each individual. It is stated by Amalia (2019). In her research, it is stated that speaking and language developments are skills to respond toward what is listened to, to deliver their intention, to follow the rules, and so forth. Thus, the skill is important to master.

Language skills should be mastered well by children. In their development process, children apply their cognitive skills to understand the concepts contained in their expressed utterances. It deals with children's skills to transform the concepts in their minds into the language of symbols according to the grammatical rules.

Based on the interview results with the Bgroup teacher and the observation result at PGRI Sarimulyo Kindergarten on Monday, January 28, 2019, there were obtained that the language skills of the learners needed to be improved. From the teacher's observation, in the last (three) years, the learners were still difficult to concentrate, to listen to the story or explanation delivered by the teacher, to retell what has been told by the teachers in a simple language, and to ask and answer questions to review the content and meaning of a story delivered by the teacher. The data informed, it could be seen that in the first semester report, 15 learners in B group of Sarimulyo PGRI Kindergarten had not reached the Excellent Development category (BSB) in Core Competency 3.11 (understanding the expressive language) and 4.11 (performing the expressive language skills). In another hand, there were 2 learners reached the Expected Development (BSH) category. 11 learners reached Early Development (MB) category. Then, there were 2 children obtained Undeveloped Category (BB).

The expressive language skill criteria are Excellently Developed (ED). It is when the mean is between 51.00 until 60.00. Expected developed (BSH) if the mean is between 41.00 until 50.00. Early Developed (ED) if the mean is between 26.00 until 40.00. Undeveloped (U) if the mean is between 15.00 until 25.00.

To improve the language skill, there is a need for an appropriate stimulation with media and the suitable method according to the age and characteristics of 5-6-year-old children. Language development stimulation requires children to provide various media and applied learning methods in learning. The applicable media that facilitates to show what is delivered concretely. Then, the applied media functions to package media delivery joyfully and interestingly for children. Dewi (2016), in her research, states that learning media is anything that could be used to deliver messages so it could trigger the interest, mind, and feeling of learners in the learning process to achieve the learning objective.

The applicable media function to describe the characteristics' natures of the story told by the teacher. Dewi (2016), in her research, applied the doll and puppet media as the alternatives in developing the early children's language skills. According to Dewi (2016), the media -promote children to involve -in learning process, so they could be more motivated in learning.

In playing the doll, the teacher could show the mimics, expressions, and natures of the characters clearly with different sounds based on the characters' natures and conditions experienced by the characters. Therefore, children would be more interested in listening to the given information from the teacher. -By applying the media, the children's attention become more focused and easy- to understand the information. -It is due to the information that is delivered interestingly and joyfully, so it 
would be much -smoothly internalized and stored in the children's - memories.

The arguments and findings discussed were also proven by Kusdiyati (2010). In her research, it concluded that providing a story with a hand-doll model would influence their Indonesian language skills.

Based on the explanations, it could be concluded that children aged 5-6 years old learn more by observing and imitating what they see from the models in front of them. In this research, the investigations were conducted to analyze the effectiveness of the symbolic modeling method assisted by a doll in the expressive language learning for the B-group children in PGRI Sarimulyo Kindergarten. The model provide the joyfull learning process to induce an effective learning an improving the learners' expressive language skills.

\section{METHOD}

A pretest-posttest control group design is applied in this experimental research. The population of this research consisted of all Bclass learners in PGRI Sarimulyo Kindergarten and Sarimulyo 02 PGRI Kindergarten, Winona Regency, Pati Municipality, in the academic year 2018/2019. It consisted of 30 learners. The selection of B-group as the research population was based on several considerations, such as (1) Children aged 5-6 years old can collaborate, are dependent in a positive manner, interactive, communicative, having personal responsibility, and respecting other people; (2) children aged 56 years old are students that have met the age requirement to promote preschool activities; (3) learners that are in the transition period from preschool level to the primary school level.

The sampling guideline is based on Roscoe. It applies guidelines to determine the sample numbers for simple experimental research. It is done by rigidly controlling the sample size, started from 10 up to 20 elements (Darmawan. 2016: 143). In this research all of the children in the population were taken as the sample. Therefore, there are 30 students as the sample. The research subjects consisted of the B- group of PGRI Sarimulyo 02 Kindergarten that has low speaking skills. There were 15 learners and grouped into the control group. Meanwhile, the learners of PGRI Sarimulyo Kindergarten, that have low speaking skills, were grouped into the experimental group.

This research was carried out within eight sessions. In the first session, a pretest was given instead of an intervention for the experimental and control groups. The pretest was given by applying the most frequently used media. It was a modeling media without any media. For the second session until the sixth session, an intervention was given for the experimental group. It was a symbolic modeling method assisted by a doll. Meanwhile, the control group was still taught by modeling method without media. A post-test was given in the eight session in which the experimental group was treated further with a symbolic modeling media assisted by a doll while the control group was still taught by a modeling method without any media.

The applied data collection is an observation technique by using observation sheets of the expressive language in the form of a checklist with a Likert scale, 1, 2, 3, and 4. The validity test of the observation sheet instrument uses expert validation to examine the content validity or construct. The instruments are constructed based on the measured aspects under certain theories. Then, the instruments are consulted with experts (Sugiyono, 2017: 173). The experts in this research are the referredlecturers of Early Childhood Children Education. The observation sheet had been consulted and approved by the expressed and deemed valid. The research instruments are taken from The Standard of Early Childhood Children Development Achievement Levels Aged 5-6 Years Old as stated by The Regulation of Educational and Cultural Minister of Republic Indonesia, Number 137, the Year 2014.

The observed-expressive language skills in this research are speaking and writing of 5-6year-old children. The descriptors of each indicator are : 1) The speaking skill: communicating orally, answering more complex 
questions, and having more data to express; 2) writing skill: recognizing the reading and writing preparation symbols, understanding the sounds, and the letter realizations. Each indicator has three descriptor items so in the expressive language observation sheet, it has 12 descriptor items.

During the observation process, the observers checked by using check mark $(\sqrt{ })$ on the obtained scores based on the arranged observation guidelines. From the observation, it was found the effectiveness of modeling method assisted by a doll to improve expressive language skills of 5-6-year-old children. The data in this research were analyzed statistically. The data deal with the expressive language of 5-6-year-old children. The applied statistic analysis in this research consists of descriptive and inferential analysis.
The findings could be seen from the Wilcoxon test, which shows an influence of the symbolic modeling method assisted by a doll toward the expressive language of 5-6-year-old children. It is then proven from the improvement of the expressive language learning outcome from the pretest and the posttest. It is also proven from the Mann Whitney test. It shows differences in the learning outcomes between the control group students taught by symbolic modeling media without media and the experimental group students taught by symbolic modeling media assisted by a doll.

The applied dolls were made of papers. They had various profession figures, such as farmers, teachers, and police officers as shown in Figure1.
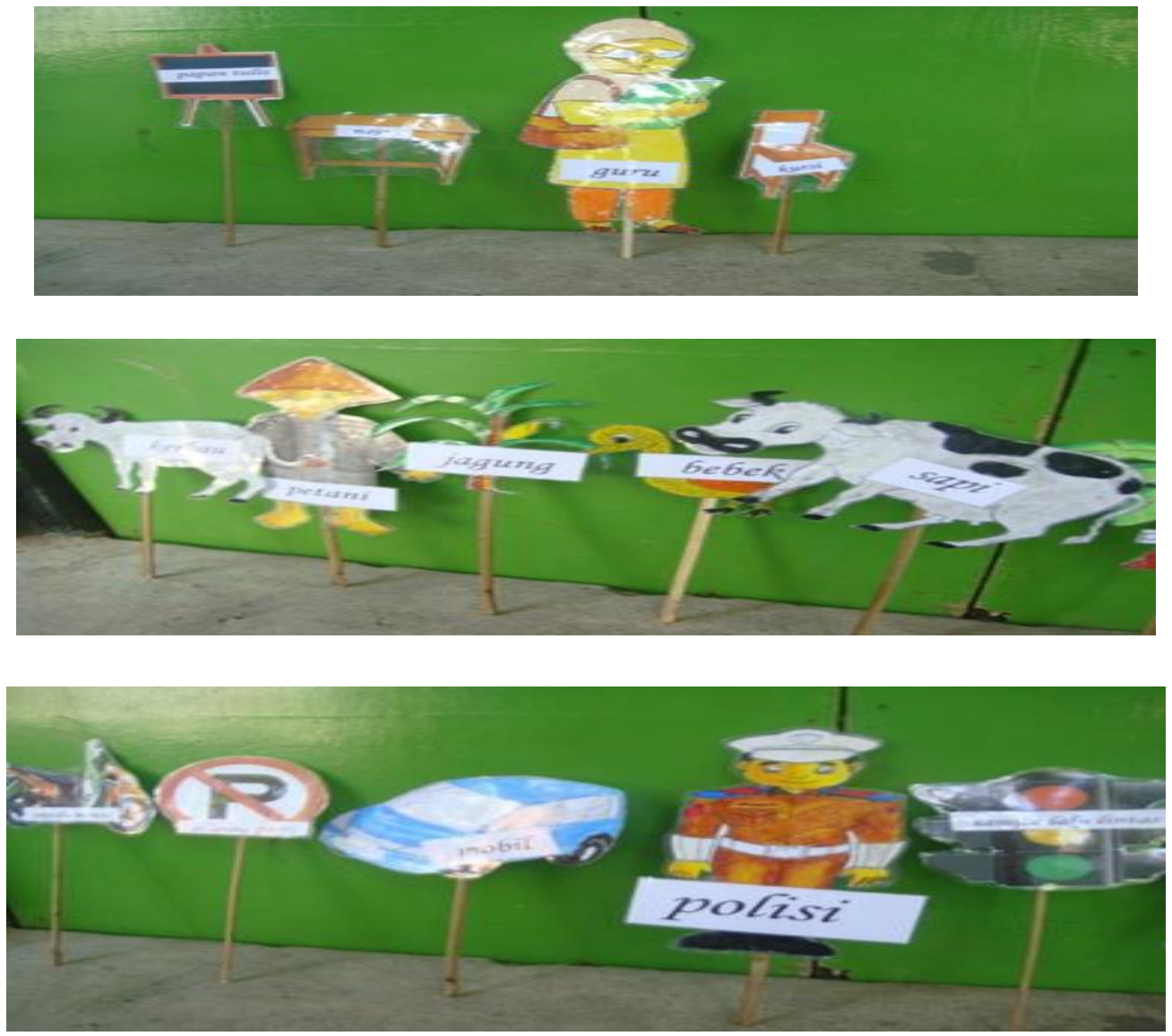

Figure 1. The Models of the Dolls

The teacher became the model by playing the dolls as the symbols of the introduced professions for the learners. The teacher played the dolls by mimicking, expressing, and speaking 
as the real characters (a teacher, a farmer, and a police officer) while introducing himself, his job, and his job instruments.

The expressive language skill development learning for 5-6-years old children by implementing the modeling method assisted by a doll was carried out with 4 stages. The stages were:

1) the teacher paid attention by introducing the applied doll for the children;

\section{RESULTS AND DISCUSSION}

2) representing: the teacher showed the dolls to describe the characters played by the dolls, describe the tasks or the affiliation in their jobs, and describe the actors' working places;

3) reproduction: the teacher invited learners to interact by asking and answering questions about the delivered material and gave them chances to describe the characters, such as a teacher; and

4) motivating: the teacher empowered on the learners' learning outcomes.

Table 1. The pretest results of the experimental and control groups could be seen in

\begin{tabular}{|c|c|c|c|c|c|c|c|c|}
\hline \multirow{2}{*}{$\mathrm{T}$} & \multicolumn{4}{|c|}{$\mathrm{EG}$} & \multicolumn{4}{|c|}{$\mathrm{CG}$} \\
\hline & $\mathrm{N}$ & $\mathrm{M}$ & $\mathrm{SD}$ & $\mathrm{K}$ & $\mathrm{N}$ & $\mathrm{M}$ & $\mathrm{SD}$ & $\mathrm{K}$ \\
\hline $\mathrm{T} 1$ & 15 & 23.5 & 3.27 & UC & 15 & 23.2 & 4.14 & UC \\
\hline
\end{tabular}

Remarks: EG = Experimental Group; $\mathrm{CG}=$ Control Group; T1 = Pretest; N = Number of Samples; $\mathrm{M}=$ Mean; SD = Standard of Deviation; UC = Uncompleted

Table 1 shows the pretest result of the expressive language skill for the experimental group shows the highest score 30, the lowest score 17 , the mean 23.53 , and the deviation standard 3.378. The pretest result shows that the expressive language skill of the children is categorized in Undeveloped (BB). The pretest result of the expressive language skill for the experimental group shows the highest score 30 , the lowest score 17, the mean 23.4, and the deviation standard 4.40. The pretest result shows that the expressive language skill of the children is categorized in Undeveloped (BB).

The pretest results of applying symbolic modeling method without the media, as promoted in the experimental and control groups, proved that either the expressive language skill of PGRI Sarimulyo kindergarten learners, aged 5-6 years old and the expressive language skills of PGRI Sarimulyo 02 Kindergarten learners, aged 5-6 years old, were still low as shown by the mean of the obtained score from Undeveloped category (BB). The pretest result shows that learning by the symbolic modeling method without media could not reach maximum results. The finding is relevant to Dewi (2016). She concludes that modeling the learning process by observing other people causes changes that occur after trying to model.

The children's behaviours are influenced by the environment. They tend to model because they learn from what they see. The findings could be defined that children learn maximally by observing and modeling what they see as the role model. It happens since without using a media as the model, learners will not see the original described model and could attract their attention in re-modeling what is done by the teachers based on the instruction. Therefore, children's expressive language skills were not developed as expected.

Table 2 describes the expressive language skill of both groups in this research. 
Table 2. The Description of the Experimental and Control Groups' Expressive Language Skills

\begin{tabular}{lllllllll}
\hline T & EG & \multicolumn{7}{c}{ CG } \\
& $\mathrm{N}$ & $\mathrm{M}$ & $\mathrm{SD}$ & $\mathrm{K}$. & $\mathrm{N}$ & $\mathrm{M}$ & $\mathrm{SD}$ & $\mathrm{K}$. \\
\hline $\mathrm{T} 1$ & 15 & 23.5 & 3.38 & $\mathrm{BB}$ & 15 & 23.4 & 4.40 & $\mathrm{BB}$ \\
$\mathrm{T} 2$ & 15 & 51.8 & 2.46 & $\mathrm{BSB}$ & 15 & 27.0 & 4.41 & $\mathrm{MB}$ \\
\hline
\end{tabular}

Table 2 shows the pretest result of 15 learners' expressive language skills in the experimental group. It shows the mean score (M) 23.53 and the SD score 3.378. The post-test result of the expressive language skills shows the mean score (M) 51.80 and SD score 2.455 . Meanwhile, in the control group, the pre-test score of the expressive language skill shows the mean score (M) 23.40 and SD score 4.404. Then, the post-test score shows the mean score (M) 27.06 and the SD score 4.41.

The post-test result shows that learning in the experimental group, intervened by the symbolic modeling method assisted by a doll, could reach the Excellent Development (BSB) category. It could be seen from the learners' enthusiasm in keeping up with the activity, playing the doll and imitating the examples from the teachers. Thus, learners could express simple matters in playing the dolls.

A doll media is made from modified boxes. They are made into several characters, such as farmers, teachers, and police officers. The dolls were equipped with holders for the children to play. The farmer, teacher, and police officer dolls were ever used in a learning activity inside of a classroom. Thus, children would be interested to play.

The speaking and communication skills of children orally were improved. It could be seen from the way they played the dolls farmers, teachers, or police officers along with their equipment. The conversations among teachers, farmers, and police officers in introducing themselves, mentioning the required tools, and telling about the jobs of the characters in a simple language. Thus, their vocabulary would be more complex.

The children's skills to recognize symbols of reading and writing preparation as well as their understanding about sound and the letter would be improved. It could be observed from their skills to mention the letters and words of the farmers, teachers, and police officers on the dolls. They could mention the shown letter correctly.

It is different from the post-test result of the control group that was taught by the symbolic modeling without assisted by the media. It could only reach the Early Development category (MB). The post-test result is relevant to Repita (2015). She concludes that through multiple modeling techniques with the teacher real model and symbolic model in the form of pictorial stories, it could be easily accepted by children. Thus, it could influence children to be better.

The argument can be defined that in administering the activity for children to be skilled in speaking and writing, there should be a proper model for them. Thus, they could easily accept and understand the delivered meaning and message. It would also make them easy to model the behaviour, style, or anything the model concretely performed for them. Table 3 shows the Wilcoxon test result of the experimental group's expressive language skills in the research. 
Table 3. The Wilcoxon test result of the experimental group's expressive language skills.

\begin{tabular}{|c|c|c|c|c|c|c|}
\hline LO & Class & $\mathrm{N}$ & Negative Ranks & Positif Ranks & Ties & $\mathrm{P}$ \\
\hline EL & $\mathrm{E}$ & 15 & $0 \mathrm{a}$ & $15 b$ & 0 & 0.00 \\
\hline
\end{tabular}

Remarks: LO = Learning Outcome, EL = Expressive Language, $\mathrm{P}=$ Asymp. Sig. (2-tailed)

Table 3 shows a negative rank, 0.00 . It means there is no decrease in the pre-test score to the post-test score. Positive Rank $\mathrm{N}=15$. It means the learners had improving scores from the pre-test to the post-test. Ties $=0$. There is no similar score from the pre-test and the post-test. Asymp. Sig. (2-Tailed) $=0.01$. It is lesser than 0.05 . It means there is a difference between the pre-test learning outcome and the post-test learning outcome. Thus, it could be concluded that the symbolic modeling assisted by a doll influences the learners' expressive language skills.

The Mann Whitney test result of the 5-6year-old expressive language skills in the experimental and control groups is described in Table4.

Table 4. The Mann Whitney test result of the 5-6 expressive language skills in the experimental and control groups is described in.

\begin{tabular}{lllll}
\hline HB & Class & $\mathrm{N}$ & $\mathrm{M}$ & $\mathrm{P}$ \\
\hline $\mathrm{BE}$ & $\mathrm{K}$. & 15 & 8.00 & .000 \\
& $\mathrm{E}$ & 15 & 23.00 & \\
\hline
\end{tabular}

Remarks: $\mathrm{LO}=$ Learning Outcome, $\mathrm{EL}=$ Expressive Language, $\mathrm{P}=$ Asymp., $\mathrm{EG}=$ Experimental Group, $\mathrm{CG}=$ Control Group, $\mathrm{N}=$ the Sample Numbers, $\mathrm{M}=$ Mean, $\mathrm{SD}=$ Standard of Deviation, BB $=$ Undeveloped, $\mathrm{MB}=$ Early Development, BSB $=$ Excellent Development Sig. (2-tailed)

Table 4 shows the descriptive analysis of the 5-6-year-old children's expressive language skill learning outcomes in the control group. It consists of 15 learners with the highest score of 34 , lowest score 19, and a mean score of 8.00 . Meanwhile, the experimental group, consisting of 15 learners, obtain the highest score 55, the lowest score 48, and the mean score 23.00 .

The statistic test output, the Mann Whitney test, of the 5-6-year-old children's expressive language. It shows that Asymp. Sig ( 2 - tailed) is $0.000<0.05$. It could be concluded that there is a difference in the experimental group's expressive language skill taught by the symbolic modeling method assisted by a doll and the control group taught by the symbolic modeling method without media.

The output of the Wilcoxon test shows there is an influence of the symbolic modeling method assisted by a doll toward the expressive language of 5-6-year-old children. It is proven from the improvement of the expressive language learning outcome from the pretest and the posttest. It is also proven from the Mann Whitney test. It shows differences in the learning outcomes between the control group students taught by symbolic modeling media without media and the experimental group students taught by symbolic modeling media assisted by a doll. Thus, it could be concluded that symbolic modeling assisted by a doll is effective to improve the expressive language skills of 5-6year-old children.

The hypothesis results are relevant to Kurniawati (2016). In her research, she states that in the kindergarten learning activity, media plays an important role in children because children are in the concrete period. Gerde (2012) in his research shows that teachers in early childhood education should offer various programs, media, and writing skill models (the expressive language) for children. Writing is an 
activity to deliver notions, arguments, and perceptions in a printed form to communicate. The argument can be defined that in administering the activity for children to be skilled in speaking and writing, there should be a proper model for them. Thus, they could easily accept and understand the delivered meaning and message as well as something to be seen from the model.

The effectiveness of symbolic modeling for early children's learning has been proven.
For example, a study conducted by Indrawati (2016) that had background based on children's difficulties in their speaking skill and their lowcategory speaking development achievement results. The research concludes that the symbolic modeling technique could improve the B-group children's speaking skills.

Table 5 consists of the applied-speaking and writing indicator summary for 5-6-year-old children.

Table 5. The Expressive Language Skill Indicators (Speaking and Writing) of 5-6-Year-Old Children

\begin{tabular}{ll}
\hline Aspects & Indicators \\
\hline Speaking & Answering the more complex question (IB1) \\
& $\begin{array}{l}\text { 2. Communicating orally (IB 2). } \\
\text { 3. Having more words to express the ideas (IB 3) } \\
\text { Writing }\end{array}$ \\
& Recognizing the symbols of reading and writing preparation (IB 4). \\
\end{tabular}

Based on table 4 , the measured aspects of an expressive language for 5-6-year-old children are answering more complex questions, and communicating orally, having more words to express. And the measuring aspects of the written expressive language skills for 5-6-yearold children are recognizing the reading and writing preparation and understanding the sound and the letter realization relationship.

Speaking and writing include a composing process. Rosyidah (2012), in her research, argues that speaking is meant to express, communicate an individual's thought, and express notion and feeling that is influenced by the listening skill. It is concluded that speaking for children has wider meanings of speaking. Speaking is defined as the sounds of the language words that could be understood by interlocutors. However, child speech is defined as the sounds produced by children either the language sounds or sounds that do not belong to language and are uttered by children's speech organs.

Janawati (2013), in the research, states that, conventionally, learning writing could be defined as children studying to paint something in a certain writing system that could be read by people who understand the system. Writing activity in kindergarten emphasizes more on activities to express their notions, feelings, and ideas through written symbols freely or independently based on formal writing principles. Writing needs fine motor, ocularhand coordination to hold stationeries and basic writing methods of letter perception and printed language.

The learning principle for early childhood is to play and learn. That statement is proven by Prahesti (2016). In her research, it has been proven that word-ball bathing and word cards are effective to introduce the initial reading and writing concepts. Kusumawati (2017), in her research, states that playing plasticine is effective to improve the initial writing skill for early childhood. Aisy (2019) also concludes that implementing card media in reading and mathematic content areas is proven effective to improve the writing skills of 4-5-year-old children. Naitili (2019), in her research, concludes that the implementation of Structural Cytetic Analytics is effective to improve the initial writing skills of first-grade students in a 
primary school. Those studies are relevant because they take similar research subjects and themes, the language skills (the initial reading and writing) of early childhood. The differences deal with the applied media and method in this research.

Those findings are relevant to the research Khasanah (2016). She states that in her research that developing the early children's language skill is o allow them to understand the mimics, tones, and the word meaning uttered by other people while explaining or describing something. Thus, children would be able to recognize and respond to other people plus to develop excellent communication with surrounding people. The applied media in the learning activity would be meaningful when it is delivered by the appropriate learning method, based on the learners' characteristics and ages.

There are many proven findings of the previous studies, such as a study conducted by Agus (2011) with a storybook; Nurhayati (2016), and Rahmawati (2017) with a picture-word media; Janawati (2013) applying word card learning in playing domino; and Sudarta (2017) applying jolly phonics method. According to Sudarta (2017), the applied method could stimulate the initial writing skills of early childhood. Those studies are relevant because they take similar research subjects and themes, the language skills (the initial reading and writing) of early childhood. The differences with this current research also deal with the applied method and media.

A study conducted by Hill (2011) concludes that the valid and practicable ecological procedures in the social-daily lives for the beginning of children's ages are effective to measure their literacy. Meanwhile, Kurniawati (2016), in her research states that a pop-up book based media for a conversational method is effective to improve the 4-5-year-old children's speaking skills. Kustina (2014) and Muyasaroh (2017), in their researches, conclude that using word cards, children's language skills could be improved. Those studies are relevant because the applied topic deals with early childhood children. The differences deal with the applied media and method in the research.

Fauzani (2016) and Farikha (2018), in their researches, found the centered-role playing learning model influenced the B-group students' expressive language skills. A similar study was done by Azizah (2013). She concludes that the language speech level for 5-6-year-old children is higher when it is intervened by the macro-role playing method than those taught by applying the micro-role playing method.

Those studies are relevant because the topic of the researches deals with the language speaking skill of 5-6-year-old children. However, for the applied learning method in the learning is different. Those three studies implemented a role-playing method to improve the learners' speaking skills. Meanwhile, in this research, the researcher examines the effectiveness of modeling methods to improve language skills.

Indrawati (2016), in her study, applied the modeling technique to improve the earlychildhood children's speaking skills. The research aims to find out the modeling technique toward B-group learners' speaking skills. The findings showed that the modeling technique could improve the speaking skill of 5-6-year-old children.

Repita (2016), in her study, states that modeling is learning done by observing with adding or reducing the observed behaviors, generalizing various observations, and involving the cognitive process. It is relevant to Indrawati's research (2016) that concludes the modeling technique is a learning process by observing. It allows individuals or several individuals to be examples. They have roles to stimulate thought, attitude, and behavior of the observing objects to be imitated.

By referring to this theory and the relevant studies, the researcher selects the symbolic modeling method assisted by a doll to examine its effectiveness in stimulating the earlychildhood children's expressive language, especially the 5-6-year-old children.

The argument is proven in this research that the experimental group, taught by the symbolic modeling assisted by a doll, is effective 
in improving the 5-6-year-old children's expressive language skills than those taught by the symbolic modeling method without assisted by the learning media. In this research, the learners in the experimental group learned from symbols, they were dolls demonstrated by a teacher.

\section{CONCLUSION}

The hypothesis test results show that the applied learning model, the symbolic modeling method, influences significantly $(\mathrm{p}<0,05)$. There is an improvement in the 5-6-year-old children's expressive language skill improvements. It is shown by the mean of the obtained scores from the expressive language skill indicators after being the intervention is in the Excellent Development (BSB) category.

\section{REFERENCES}

Azizah N, \& Kurniawati Y. (2013). Tingkat Keterampilan Berbicara ditinjau dari Metode Bermain Peran pada Anak Usia Dini 5-6 tahun. Ijeces, indonesian journal of early childhood education studies. 2 (2): 50-57.

Agus, J. R., \& Winiharti, M. (2011). The Analysis Of Creative Writing Teaching Through Story Book Reading For The First Grade Students Of Tunas Muda International School. Jurnal LINGUA CULTURA. 5(2): 98-107.

Aisy, A. R., \& Adzani, H. N. (2019). Pengembangan Kemampuan Menulis pada Anak Usia 4-5 tahun di TK Primagama. Jurnal Pendidikan Anak 8(2): 141-148.

Darmawan, D. (2016). Metode penelitian Kuantitatif. Bandung: PT. Remaja Rosdakarya

Dewi, D. K. E. (2016). Penerapan Teknik Modeling Untuk Meningkatkan Disiplin Pada Anak Usia 5-6 Tahun. e-Journal PAUD Universitas Pendidikan Ganesha Jurusan Pendidikan Guru Pendidikan Anak Usia Dini, 4(3)
Farikha, L. (2018). Pengaruh Model Pembelajaran Sentra peran Terhadap Kemampuan Berbicara Anak Usia 5-6 Tahun di TK Islam Al- Khalifa Solerejo Mojowarno Jombang. Trunojoyo: Jurnal Pendidikan dan Pembelajaran Anak Usia Dini, 5(1): 45-55.

Fauzani, B.N., \& Mas'udah. (2016). Pengaruh Model Pembelajaran Sentra Main Peran Terhadap Kemampuan Bahasa Ekspresif Anak Kelompok B. PG PAUD Surabaya, Jurnal PAUD TERATAI, 05 (02): 62-67.

Gerde, Hope K., Bingham, G.E., \& Wasik, B. A. (2012). "Writing in Early Childhood Classrooms: Guidance for Best Practices". Early Childhood Education Jurnal. 40(6): 351-359.

Hill, S. M., Stacy. A. ., \& Louis. M. (2017). Word Learning During Reading: Effects of Language Ability in School-Age Children. Communication Disorders Quarterly. 39(1) 270-280.

Indrawati, Ni Putu Vivin., Ni Ketut Suami., \& Putu Rahayu Ujianti. (2016). Implementasi Teknik Modelling untuk Meningkatkan Kemampuan Berbicara pada Anak Kelompok B1. e-Journal Pendidikan Anak Usia Dini Universitas Pendidikan Ganesha.4(2).

Janawati, D. P. A., Sudiana, N. \& Dantes, N. (2013). Pengaruh Implementasi Pembelajaran Kartu Kata dalam Permainan Domino terhadap peningkatan kemampuan membaca menulis Permulaan Siswa. E- Journal Program Pascasarjana Universitas pendidikan Ganesha, 3(1): 1-10.

Khasanah, N., \& Darsinah. (2016). Metode Bercerita Berpengaruh Terhadap Kemampuan Bahasa Reseptik Anak. Surakarta: eprint.ums, 2-10.

Kusdiyati, S., Lilim, H., \& Farrah, A., (2010). Pengaruh Pemberian Dongeng dengan Boneka Tangan Terhadap Kemampuan Berbahasa Indonesia. Bandung: Fakultas Psikologi Universitas Islam. 3(2): 157168. 
Kustina, R. (2014). Penggunaan media Kartu kata dalam Meningkatkan kemampuan Berbicara Anak Kelompok B TK Bungong Seleupok Universitas Syiah Kuala Banda Aceh. Universitas Syiah Kuala Banda Aceh: Jurnal metamorfosa. 2(1): $35-42$.

Kurniawati, N. (2016). Pengaruh Metode Bercakap- cakap Berbasis Media Pop-Up Book Terhadap Kemampuan Berbicara Anak Kelompok A. Jurnal PAUD Teratai. 05 (03): 68-72.

Kusumawati, A., \& Sunaria. (2017). Peningkatan Kemampuan Menulis Permulaan pada Anak Usia 5-6 tahun melalui Permainan Plastisin. YaaBunayya: Jurnal Pendidikan Anak Usia Dini, 1(1): 7-12.

Muyasaroh, S. (2017). Meningkatkan Kemampuan Berbicara Melalui Media Kartu kata Bergambar pada Anak Usia 34 tahun KB SPS Nur Amin Ridwan Gadingmangu Jombang. Jurnal PAUD Teratai, 6(3): 1-6.

Naitili, C. A. (2019). Penerapan Metode Struktural Analitik Sintetik untuk Meningkatkan Keterampilan Menulis Permulaan Siswa Sekolah Dasar. Malang: jurnal pendidikan. 4(5): 660-667.

Nurhayati, N. \& Widayati, S. (2016). Meningkatkan Kemampuan Menulis Permulaan melalui Media Pasir pada
Anak Kelompok A di TK Kyai Hasyim. PAUD Teratai, 5(1): 1-5.

Rahmawati, R. (2017). Strategi Pembelajaran Membaca dan Menulis Permulaan melalui Media Kartu Bergambar. SAP (Susunan Artikel pendidikan), 1(3):259270.

Repita, L. E., Desa, P. P., \& Luh. A. T. (2016). Implementasi Teknik Modeling Untuk Meminimalisasi Perilaku Bermasalah Oppositional Defiant Pada Anak Kelompok B. Journal PAUD Universitas Pendidikan Ganesha Jurusan Pendidikan Guru Pendidikan Anak Usia Dini. 4(2).

Rosyidah, N. (2019). Pengaruh Media Bontasi (Boneka Tiga Dimensi) Terhadap Keterampilan Berbicara Anak Usia 4-5 Tahun di TK Islam Al-Manar Wiyung Surabaya. Jurnal Paud Teratai Unesa. 1(1): 1-7.

Santrock, J. W. (2008). Psikologi Pendidikan Edisi Kedua. Jakarta: Erlangga.

Sudiarta, I. W. (2017). Pengaruh Metode Jolly Phonics Terhadap Kemampuan Membaca dan Menulis Permulaan Bahasa Inggris pada Anak Kelompok B TK Mahardika Denpasar. Jurnal Ilmiah Pendidikan dan Pembelajaran Ganesha, 1(3): $240-251$.

Sugiyono. (2018). Metode Penelitian Kuantitatif. Bandung: Alfabeta. 